\title{
Preparation of PbS/NiO Composite Photocathode and Their Applications in Quantum Dot Sensitized Solar Cells
}

\author{
Shuang Liu ${ }^{1,2}$, Lu Liu ${ }^{2}$, Qingzhuo $\mathrm{Du}^{2}$, Zeyuan $\mathrm{Ma}^{2}$, Yuhang $\mathrm{Fu}^{2}$, Yajun Zhao ${ }^{2}$, Xiaowei $\mathrm{Li}^{2}$ and Xiaohui Zhao ${ }^{2 *}$ \\ ${ }^{1}$ College of Quality Technology Supervision, Hebei University, Baoding 071002, China \\ ${ }^{2}$ Hebei Key Lab of Optic-electronic Information and Materials, College of Physics Science and Technology, Hebei University, \\ Baoding 071002, China
}

\section{Corresponding Author Email: xhzhao@hbu.edu.cn}

\begin{abstract}
The nanosized urchin-like $\mathrm{NiO}$ was synthesised by a simple hydrothermal method at high temperature, and a variety of comparative experiments were designed for studying the influence of different chemical bath deposition (CBD) cycles of PbS deposition on the photoelectric properties of quantum dot sensitized solar cells. Moreover, a novelty modified $\left.\left(\mathrm{CH}_{3}\right)_{4} \mathrm{~N}\right)_{2} \mathrm{~S} /\left(\left(\mathrm{CH}_{3}\right)_{4} \mathrm{~N}\right)_{2} \mathrm{~S}_{n}$ electrolyte was introduced in this solar cell successfully and NiS as the counter electrode. The result suggested that the maximum power conversion efficiency of $1.07 \%$ was obtained when after three $\mathrm{CBD}$ cycles of $\mathrm{PbS}$, with a significantly open circuit voltage $\left(V_{o c}\right)$ of $0.538 \mathrm{~V}$, a high short circuit current density $\left(J_{s c}\right)$ of $8.53 \mathrm{~mA} \mathrm{~cm}^{-2}$ and a fill factor (ff) of $0.23 \%$.
\end{abstract}

Keywords: oxides, electrochemical measurements, chemical synthesis, electrochemical properties Received: November-30-2019, Accepted: December-08-2019, https://doi.org/10.14447/jnmes.v23i1.a02

\section{INTRODUCTION}

Quantum dot-sensitized solar cells (QDSCs) are a promising alternative to dye-sensitized solar cells (DSCs), which attracted significantly interest in recent years due to its low cost, easy fabrication, and high theoretical power conversion efficiency [1-4]. Most QDSCs were focused primarily on the research of n-type semiconductor oxide, such as $\mathrm{TiO}_{2}$ [5], $\mathrm{ZnO}$ [6], and $\mathrm{SnO}_{2}$ [7], where photocurrents arise from photoexcited electrons injection into [8-10]. In 1999, He et al. [11] reported the first use of p-type semiconductor oxides as photocathodes in solar cells. Ever since, p-type semiconductors were increasingly further researched by a great many relevant groups. P-type photocathodes carriers transport were hole injection from the QDs into the p-type semiconductors instead of electron injection compared to ntype photoanodes $[12,13]$.

$\mathrm{NiO}$ is a most popular p-type semiconductor oxide with good stability and transparency properties for sensitized photocathodes $[14,15]$. In addition, it has also been used as a photocathode material because its wide band gap from energy range from 3.6 to $4.0 \mathrm{eV}$. Combining such photocathodes with photoanodes in a tandem photoelectrochemical solar cell, whose cell voltages and theoretical efficiency would be far higher than single junction solar cell [16]. Nevertheless, the current depends on the lower current of n-type and p-type solar cell, so the high theoretical power conversion efficiency has not been realized, resulting from the fact that the current of such tandem structure systems so far been limited by the poor performance of the p-type solar cell. Photocurrent matching is essential to obtain good photoelectric conversion efficiency tandem solar cell [17]. As a result, the development and study of p-type photocathodes in the tandem structure systems might pave way for the promising photoelectric characteristic of the solar cell.
Previous studies with conventional dye-sensitized solar cells (DSCs) showed that electron transfer photoanodes were more efficient than hole injection photocathodes. One reason was that fast recombination of holes injected into the $\mathrm{NiO} \mathrm{VB}$ when dye molecules reduced [18, 19]. Therefore, one approach that potentially could solve the problem was replacing the dye with inorganic semiconductor quantum dots such as $\mathrm{CdS}$, $\mathrm{CdSe}, \mathrm{ZnS}$ and $\mathrm{PbS}[16,20]$. Inorganic semiconductor QDs exhibits several advantages over organic dyes, such as low cost, easy obtain ability, convertibility of band gap and high molar extinction coefficient [15, 21-22]. What's more, the high extinction coefficient of semiconductor nanocrystals make light absorption improve [23], and smaller hole transport resistance for faster transport [14]. Among these nanomaterials, lead sulfide $(\mathrm{PbS})$ is a promising material that has been reported to have proper band gap of about $0.8 \mathrm{eV}$ in the material, which could be tuned to absorb band in the nearIR of the solar spectrum [24-26]. However, up to now, the use of $\mathrm{PbS}$ deposited p-type $\mathrm{NiO}$ photocathode in the QDSCs has not been reported.

In 2009, Rhee et al. [27] experimentally demonstrated ptype $\mathrm{Cu}_{2} \mathrm{~S}$ sensitized p-type $\mathrm{NiO}$ solar cell synthesised by depositing $\mathrm{Cu}_{2} \mathrm{~S}$ quantum dot on the mesoporous $\mathrm{NiO}$ photocathode for the first time, and open-circuit voltage of 91$95 \mathrm{mV}$ and short-circuit current of 260-360 mA were eventually obtained. The conversion efficiency for $\mathrm{CdSe}$ sensitized p-type $\mathrm{NiO}$ solar cells to a best report of $0.35 \%$ had been reached by Park and co-workers. In 2016, Raissi et al. [28] reported the fabrication of NiO-based QDSCs using PbS QDs with a cobalt electrolyte and Pt counter. Finally the best conversion efficiency of solar cell achieved $0.4 \%$.

In the paper, the nanosized urchin-like $\mathrm{NiO}$ was prepared by a simple hydrothermal method at high temperature [29, 30]. and narrow band gap $\mathrm{PbS}$ quantum dots (QDs) were grown on $\mathrm{NiO}$ film by Chemical Bath deposition (CBD) 
method [31-35]. A modified $\left.\left(\mathrm{CH}_{3}\right)_{4} \mathrm{~N}\right)_{2} \mathrm{~S} /\left(\left(\mathrm{CH}_{3}\right)_{4} \mathrm{~N}\right)_{2} \mathrm{~S}_{\mathrm{n}}$ electrolyte was successfully employed in PbS QDs (Figure 1). Here we show for the first time that $\mathrm{PbS}$ quantum dots were deposited on $\mathrm{NiO}$ solar cell. To the best of our knowledge, the $J_{s c}\left(8.53 \mathrm{~mA} / \mathrm{cm}^{2}\right)$ and power conversion efficiency $(1.07 \%)$ are the highest values for the QD-sensitized p-type NiO solar cells.

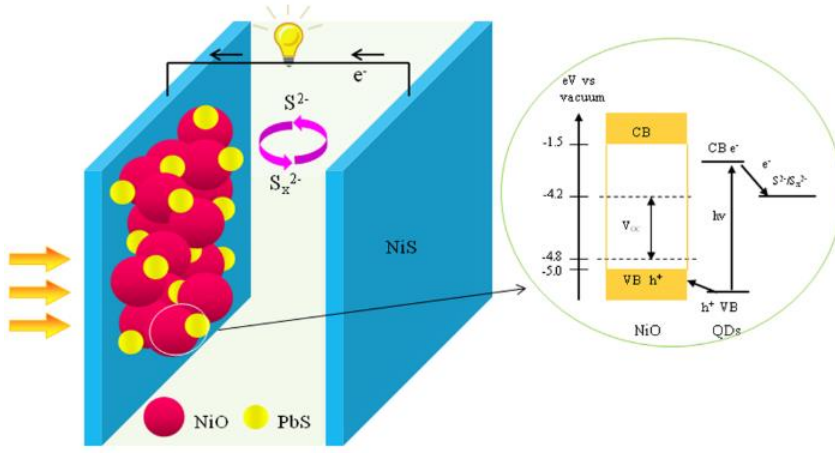

Figure 1. A schematic diagram illustrating the working principle of $\mathrm{PbS}$-sensitized mesoscopic p-NiO solar cells

\section{EXPERIMENTAL}

\subsection{Material}

All compounds were purchased either from Aladdin Inc. or from Macklin Inc. Their chemical names and purities are given in Table 1.

Table 1. Materials

\begin{tabular}{|c|c|c|}
\hline Chemical name & $\begin{array}{l}\text { Purity, } \\
\text { wt.\% }\end{array}$ & Vendor \\
\hline $\mathrm{NiCl} 2 \cdot 6 \mathrm{H} 2 \mathrm{O} \mathrm{Na} 2 \mathrm{~S}=9 \mathrm{H} 2 \mathrm{O}$ & 99.99 & \multirow{4}{*}{$\begin{array}{l}\text { Aladdin } \\
\text { Inc. }\end{array}$} \\
\hline $\begin{array}{c}\text { Urea } \\
\mathrm{Pb}(\mathrm{NO} 3) 2\end{array}$ & 99 & \\
\hline $\begin{array}{c}\text { Ethanol, methanol, thioglycolic acid, } \\
25 \mathrm{wt} \% \text { Tetramethylammonium hydroxide } \\
\text { methanol, } 20 \mathrm{wt} \%(\mathrm{NH} 4) 2 \mathrm{~S} \text { aqueous } \\
\text { solution }\end{array}$ & - & \\
\hline $\mathrm{Ni}(\mathrm{NO} 3) 2 \cdot 6 \mathrm{H} 2 \mathrm{O}$ & 98 & \\
\hline Sublimed sulfur & 99.95 & \multirow{3}{*}{$\begin{array}{l}\text { Macklin } \\
\text { Inc. }\end{array}$} \\
\hline $\begin{array}{l}\text { 3-Methoxypro-pionitrile, } 4 \text {-tert- } \\
\text { butylpyridine }\end{array}$ & 98 & \\
\hline Lithium perchlorate & 99.9 & \\
\hline
\end{tabular}

$\mathrm{NiCl} 2 \cdot 6 \mathrm{H} 2 \mathrm{O}$ (99.99\%), ethanol, methanol, thioglycolic acid, $\mathrm{Pb}(\mathrm{NO} 3) 2 \quad(99 \%), \quad \mathrm{Na} 2 \mathrm{~S}=9 \mathrm{H} 2 \mathrm{O} \quad$ (99.99\%), $\mathrm{Ni}(\mathrm{NO} 3) 2 \cdot 6 \mathrm{H} 2 \mathrm{O}$ (98\%), Sublimed sulfur (99.95\%), Tetramethylammonium hydroxide solution (25\% in methanol), Ammonium sulfide solution (20\% in H2O) were purchased from aladdin. 3-Methoxypro-pionitrile (98\%), 4-tertbutylpyridine (98\%), Lithium perchlorate $(99.9 \%)$ were obtained from Macklin.

\subsection{Synthesis of urchin-like NiO nanoparticles}

$\mathrm{NiCl} 2.6 \mathrm{H} 2 \mathrm{O}(2.377 \mathrm{~g})$ was dissolved in $20 \mathrm{~mL}$ of deionized (DI) water, after which $10 \mathrm{~mL}$ of $1 \mathrm{M}$ urea solu tion was added slowly poured under constant mixing for $30 \mathrm{~min}$, after which the mixture was placed into a $100 \mathrm{~mL}$ Teflon-lined stainless steel autoclave cup. The hydrothermal reaction was performed at $120{ }^{\circ} \mathrm{C}$ for $8 \mathrm{~h}$. The formed solids were centrifuged, rinsed with DI water and ethanol several times, dried at $80{ }^{\circ} \mathrm{C}$ for 12 $\mathrm{h}$, and then annealed at $400{ }^{\circ} \mathrm{C}$ for $2 \mathrm{~h}$.

\subsection{Electrode fabrication}

To synthesis NiO photocathodes, the obtained paste was coated on the clean FTO conducting glass (TEC15, 15 V/square, Pilkington, USA) by screen printing, which was remained at $120^{\circ} \mathrm{C}$ for $5 \mathrm{~min}$. This step was continued for 6 times. The $\mathrm{NiO}$ electrodes were uniformly sintered at $500^{\circ} \mathrm{C}$ for $30 \mathrm{~min}$.

Chemical bath deposition (CBD) was used to prepare PbSQDs sensitized $\mathrm{NiO}$ photoelectrode. First, NiO films (fabricated as described in the previous paragraph) were immersed into $0.1 \mathrm{M}$ thioglycolic acid for $1 \mathrm{~min}$, and then into $0.5 \mathrm{M}$ ethanol solution of $\mathrm{Pb}\left(\mathrm{NO}_{3}\right)_{2}(0.5 \mathrm{M})$ (also for $1 \mathrm{~min}$ ). After the samples were dried, they were immersed into $0.5 \mathrm{M}$ $\mathrm{Na}_{2} \mathrm{~S}$ solution for $1 \mathrm{~min}$ and then dried. This step was repeated 1-4 times. The resulting electrodes were marked as " $\mathrm{NiO} / \mathrm{PbS}-$ $\mathrm{N}$ ", where $\mathrm{N}$ is the number of the cycles. The working NiS electrode was divided with a hot-melt Surlyn 1702 film (25 $\mu \mathrm{m}$, DuPont). Glass substrate was immersed into $0.5 \mathrm{M}$ $\mathrm{Ni}\left(\mathrm{NO}_{3}\right)_{2}$ solution (in ethanol) for $30 \mathrm{~s}$, dried, soaked for $30 \mathrm{~s}$ in $0.5 \mathrm{M} \mathrm{Na}_{2} \mathrm{~S}$ solution (in methanol) and dried. This step was repeated up to 5 times.

\subsection{QDSC fabrication}

The QDSCs were assembled employing the PbS sensitized $\mathrm{NiO}$ photocathode and the $\mathrm{NiS}$ counter electrode as well as shelled with the conductive sides facing inward. The polysulfide electrolyte was poured into the joint between two electrodes. The polysulfide electrolyte was composed of 0.01 $\mathrm{M}$ tetramethyl ammonium sulfide $\left(\left(\mathrm{CH}_{3}\right)_{4} \mathrm{~N}\right)_{2} \mathrm{~S}, 0.02 \mathrm{M}$ 4-tertbutylpyridine (TBP), $0.02 \quad \mathrm{M} \mathrm{LiClO}_{4}, 0.002 \mathrm{M} \mathrm{S}$, 3Methoxypro-pionitrile (MPN) was served as a solvent for the polysulfide electrolyte. The $\left(\left(\mathrm{CH}_{3}\right)_{4} \mathrm{~N}\right)_{2} \mathrm{~S}$ was synthesised by heating tetramethyl ammonium hydroxide $\left(\left(\mathrm{CH}_{3}\right)_{4} \mathrm{~N}\right) \mathrm{OH}$ and ammonium sulfide $\left(\mathrm{NH}_{4}\right)_{2} \mathrm{~S}$ at $100^{\circ} \mathrm{C}$.

\section{OPTICAL AND MEASUREMENTS \\ PHOTOVOLTAIC}

Crystallinity and phase compositions were analyzed by Xray diffraction $(\mathrm{XRD})$ performed using the $\mathrm{XD}-3 \mathrm{~A}$ instrument operated using $\mathrm{CuK} \alpha$ radiation and a scintillation counter. Sample chemical composition was analyzed by energy dispersive spectroscopy (EDS) coupled with a scanning electron microscope (SEM) fabricated by Oxford Inca. UV-vis absorption spectra were collected using a U-4100 spectrometer (fabricated by HITACHI, Japan). The incident photon-tocurrent conversion efficiency (IPCE) was measured by a Hypermonolight instrument model SM-25 fabricated using Jasco Co. (Japan). Photocurrent density-voltage measurements were performed at $100 \mathrm{~mW} / \mathrm{cm}^{2}$ incident light intensity using AM 1.5G solar simulator model 16S-002 calibrated using standard $\mathrm{Si}$ solar cell and fabricated by SolarLight Co. (USA). Total testing areas of the solar cells as $0.159 \mathrm{~cm}^{2}$. Linear sweep voltammetry (LSV) was employed to obtain $J-V$ curves using an electrochemical workstation model LK9805 fabricated by Lanlike Co. (China). Electrochemical impedance spectroscopy (EIS) was conducted in the dark at - 
$0.75 \mathrm{~V}$ bias using an impedance/gain-phase ZENIUM analyzer fabricated by ZAHNER (Germany). All tests performed using the same electrolyte. The spectra were collected in the $10^{-1}-10^{5}$ $\mathrm{Hz}$ frequency range at room temperature at $10 \mathrm{mV}$ alternate current (AC) amplitude.

\section{RESULTS AND DISCUSSION}

\subsection{SEM analysis and TEM analysis}

Scanning Electron Microscope (SEM) and transmission electron microscopy (TEM) images are investigated to display the morphology and structure of $\mathrm{NiO}$ nanoparticles (Figure 2ab) and $\mathrm{PbS} / \mathrm{NiO}$ composites (Figure 2c-d). As shown in Figure $2 \mathrm{a}$, the urchin-like architecture $\mathrm{NiO}$ is obviously observed by the low-magnification SEM image, the diameters of the NiO nanoparticles can be estimated about $1 \mu \mathrm{m}$. Besides, the SEM image of the high magnification is presented in Figure $2 b$, which can be observed that each urchin composing numerous nanowires. These nanowires are equally arranged, which have a typical diameter in the range of 20 to $50 \mathrm{~nm}$. Similar observations are made in the TEM images of the samples. The TEM image in Figure 2c presents the morphology of the $\mathrm{PbS} / \mathrm{NiO}$ composites, which indicates that $\mathrm{PbS}$ are successfully deposited on the NiO. The lattice pattern of $\mathrm{PbS} / \mathrm{NiO}$ composites are declared in the HRTEM image in Figure 2d.
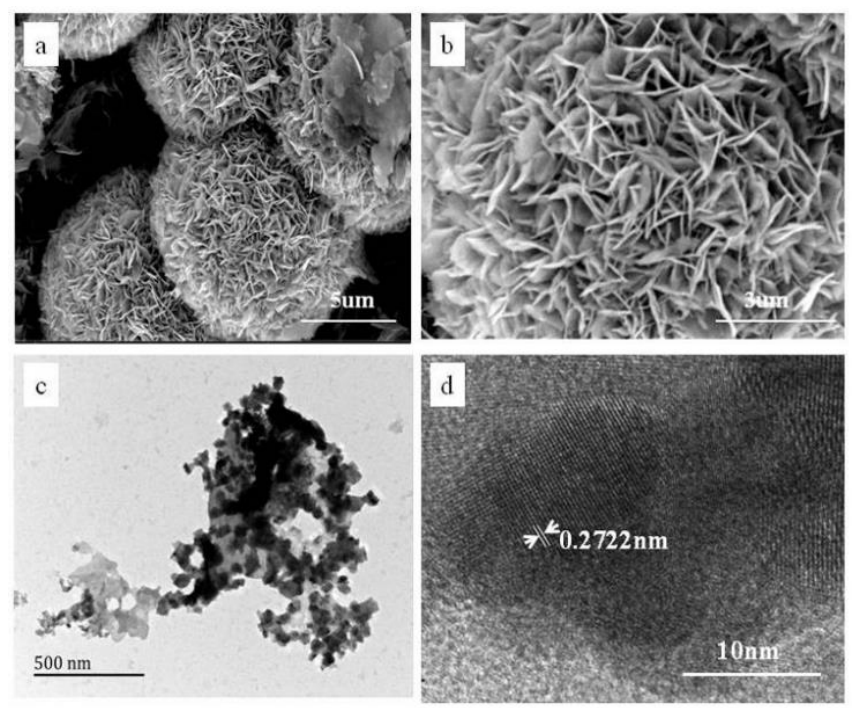

Figure 2. SEM images of $\mathrm{NiO}$ nanoparticles (a) low magnification; (b) high magnification; (c) TEM images of $\mathrm{PbS} / \mathrm{NiO}$ composites $(\mathrm{d})$ the high resolution lattice pattern of $\mathrm{PbS} / \mathrm{NiO}$

\subsection{XRD analysis}

The crystal structures of $\mathrm{NiO}$ and the deposited $\mathrm{PbS}$ are further characterized by X-ray diffraction (XRD). In the pattern of the pure $\mathrm{NiO}$ film reveals a bunsenite phase at 43.16 (200), with other planes (111), (220), (311). All the values are in good agreements according to JCPDS-02-1216. After deposition of $\mathrm{PbS}$ Quantum-dots on the surface of $\mathrm{NiO}$ thin film, the new diffraction peak is perfectly indexed to scattering from the (111), (200), (220) and (311) planes. Furthermore, the obtained values are in accord with the previously reported data (JCPDS card NO.05-0592), indicating that the $\mathrm{PbS}$ is a pure galena phase. The result further confirmes that nanoparticle composites are composed of both wellcrystallized $\mathrm{PbS}$ nanoparticles and bunsenite $\mathrm{NiO}$. In addition, there are no obvious peaks for impurity on the patterns, which indicates that the sample is pure and no other impurities generated during the process.

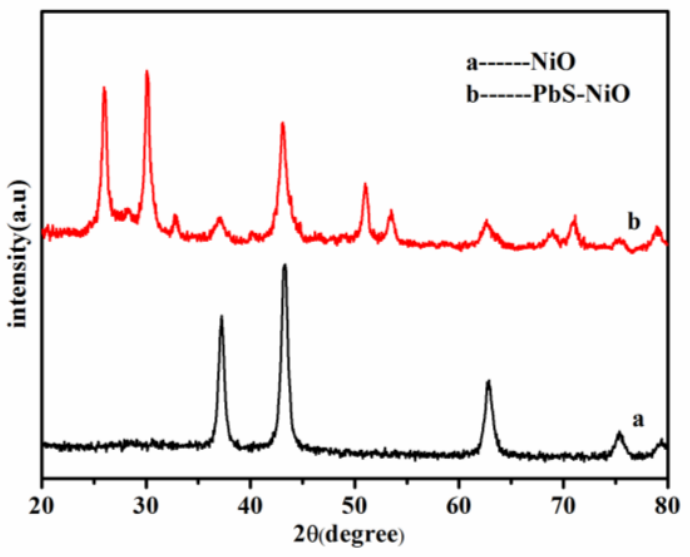

Figure 3. $\mathrm{XRD}$ spectra of $\mathrm{NiO}$ (a) and $\mathrm{NiO} / \mathrm{PbS}(\mathrm{b})$

\subsection{Elemental composition}

The bulk composition analysis of the $\mathrm{PbS}$ deposited $\mathrm{NiO}$ are carried out by energy dispersive X-Ray (EDS) spectrometer. As shown in Figure 4, we can clearly see characteristic peaks corresponding to $\mathrm{Ni}$ and $\mathrm{O}$ elements, deriving from the $\mathrm{NiO}$. The small peak observed for $\mathrm{Pb}$ and $\mathrm{S}$ demonstrates the existence of $\mathrm{Pb}$ and $\mathrm{S}$ in the $\mathrm{NiO}$ substance. Moreover, the atomic percent of $\mathrm{O}$ and $\mathrm{Ni}$ was 47.65: 42.46, indicating that the O: Ni ratios is about 1.12:1.0 for NiO. Theoretically, the atomic ratios measured by EDS are relatively closed to their stoichiometries. Therefore, the chemical formulae of the $\mathrm{NiO}$ can be expressed according to their stoichiometric ratios. Similarly, the atomic percent of $\mathrm{S}$ and $\mathrm{Pb}$ is 5.01: 4.88, demonstrating that the $\mathrm{S}: \mathrm{Pb}$ ratios is nearly 1.03:1.0 for $\mathrm{PbS}$, the same conclusion can be seen according to the aromic percent of $\mathrm{Pb}$ and $\mathrm{S}$. The result shows that a successfully deposition of $\mathrm{PbS}$ layer covers the $\mathrm{NiO}$ surface with a small amount.

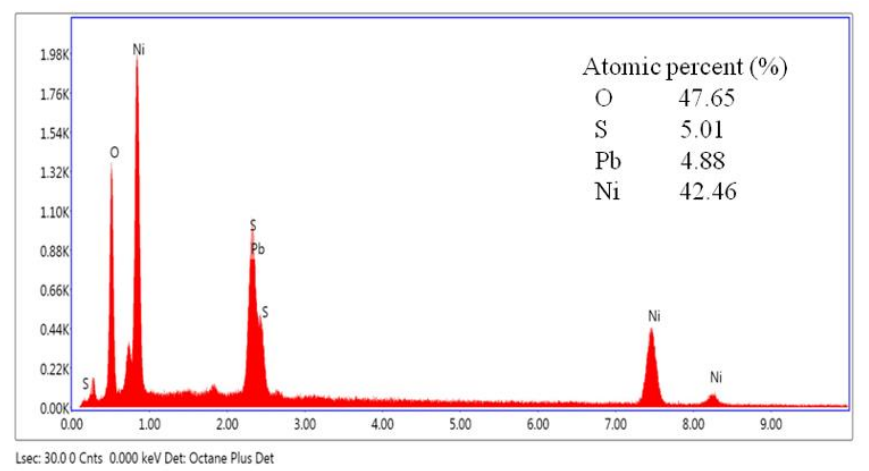

Figure 4. EDS analysis of $\mathrm{PbS} / \mathrm{NiO}$ nanocomposite

\subsection{UV-Vis absorption spectra}

$\mathrm{UV}-\mathrm{Vis}$ absorption spectra of pure and $\mathrm{PbS}$-modified $\mathrm{NiO}$ films showed color change and absorbance increase as number 
of $\mathrm{PbO}$ deposition cycles increased (see Figure 5) from 0 to 4. The UV-Vis absorption spectra of $\mathrm{NiO}$ mesoporous film and $\mathrm{PbS}$ QDs deposited $\mathrm{NiO}$ mesoporous film. For the procedure displayed on the $\mathrm{NiO}$ mesoporous film, the thickness of $\mathrm{PbS}$ QDs deposition is large, as suggested by the observation of a color change in the film and the higher absorbance of the $\mathrm{NiO} / \mathrm{PbS}$ electrode. It is clearly noticed that the absorbance is increased when CBD cycles increased, and the absorption shoulder also shows an obvious red shift compare to absorbance onset. The $\mathrm{PbS} / \mathrm{NiO}$ material absorbance shoulder became red-shifted as number of $\mathrm{PbO} \mathrm{CBD}$ cycles increased. Absorption wavelength of $\mathrm{NiO} / \mathrm{PbS}-4$ and pure $\mathrm{NiO}$ film immersed in $((\mathrm{CH} 3) 4 \mathrm{~N}) 2 \mathrm{~S} /((\mathrm{CH} 3) 4 \mathrm{~N}) 2 \mathrm{Sn}$ electrolyte was in the $490-550 \mathrm{~nm}$ range, which is beneficial for light capture and enhanced photoelectric efficiency.

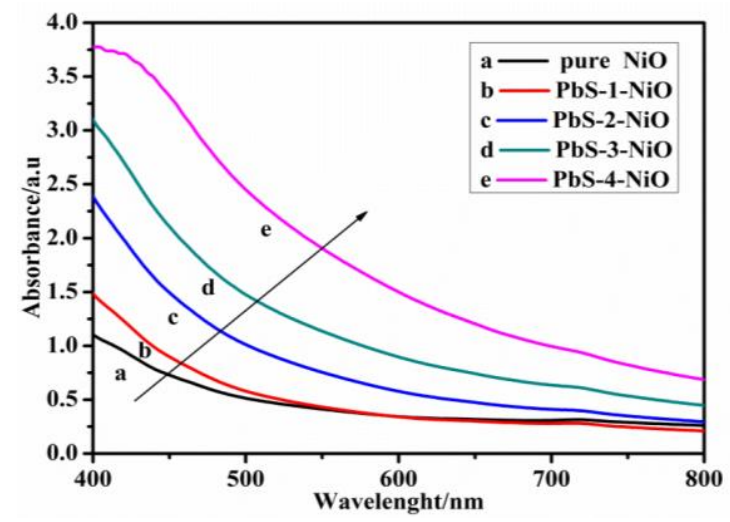

Figure 5. UV-vis absorption spectra of pure and $\mathrm{PbS}$ modified $\mathrm{NiO}$ films fabricated using different number of CBD cycles

\subsection{J-V characteristics}

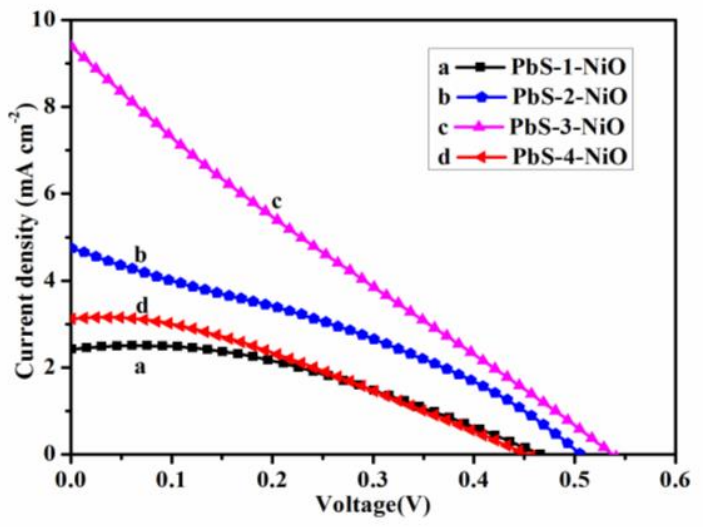

Figure 6. The $\mathrm{J}-\mathrm{V}$ data obtained for pure and PbS-modified $\mathrm{NiO}$ films obtained using different number of CBD cycles.

Measurements were conducted under solar light illumination (AM 1.5, $100 \mathrm{~mW} \mathrm{~cm}^{-2}$ )

Table 2. Photovoltaic performance of the QDSCs containing $\mathrm{NiO} / \mathrm{PbS}-\mathrm{N}(\mathrm{N}=1-4)$ materials under illumination by the solar light. Areas of all cells were $0.159 \mathrm{~cm} 2$.

\begin{tabular}{cccccc}
\hline Sample ID & $\begin{array}{c}\text { Cell area } \\
\left(\mathbf{c m}^{\mathbf{2}}\right)\end{array}$ & $\mathbf{V}_{\text {oc }}(\mathbf{V})$ & $\begin{array}{c}\mathbf{J}_{\text {sc }}(\mathbf{m A} \\
\left.\mathbf{c m}^{-2}\right)\end{array}$ & FF & $\begin{array}{c}\text { Eff/ } \\
\text { \% }\end{array}$ \\
\hline $\mathrm{NiO} / \mathrm{PbS}-1$ & 0.159 & 0.467 & 2.20 & 0.41 & 0.42 \\
$\mathrm{NiO} / \mathrm{PbS}-2$ & 0.159 & 0.507 & 4.31 & 0.33 & 0.73 \\
$\mathrm{NiO} / \mathrm{PbS}-3$ & 0.159 & 0.538 & 8.53 & 0.23 & 1.07 \\
$\mathrm{NiO} / \mathrm{PbS}-4$ & 0.159 & 0.454 & 2.84 & 0.34 & 0.44 \\
\hline
\end{tabular}

Figure 6 and Table 2 demonstrate the current densityphotovoltage $(\mathrm{J}-\mathrm{V})$ data for QDSCs fabricated using $\mathrm{NiO} / \mathrm{PbS}$ as active material.

As the number of CBD cycles increased from one to three, both short-circuit current density (Jsc) and open-circuit voltage (Voc) increased from $2.20 \mathrm{~mA} / \mathrm{cm} 2$ and $0.467 \mathrm{~V}$ to $8.53 \mathrm{~mA} / \mathrm{cm} 2$ and $0.538 \mathrm{~V}$, respectively. A maximum PCE value of $1.07 \%$ was obtained by the electrode containing PbS$3-\mathrm{NiO}$ as active material. Thus, $\mathrm{PbS}$ thickness obtained after three CBD cycles was the best because it provided the highest number of excited electrons capable to improve QDSC photocurrent. After three CBD cycles, $\mathrm{PbS}$ layer became too thick for efficient electron injection an excitation mostly because of increased number of recombination in. This also indicates that a thick $\mathrm{PbS}$ nanoparticles layer will hinder the regeneration of $\mathrm{PbS}$ by the polysulfide electrolyte and enlarge the rate of the recombination reaction.

\subsection{IPCE spectrum}

IPCE spectra of p-type QDSCs containing $\mathrm{PbS} / \mathrm{NiO}-\mathrm{N}$ composites as active materials (shown in Figure 7) had the same shapes as corresponding absorption spectra. Thus, the photocurrents were generated because of the hole injection from the photo-excited $\mathrm{PbS}$ to $\mathrm{NiO}$. The IPCE response for the $\mathrm{PbS} / \mathrm{NiO}-3$ material was the largest. The maximum IPCE response of the sensitized $\mathrm{NiO}$ was $49 \%$ at $340 \mathrm{~nm}$. Such high IPCE value is reported for the first time for the p-type QDSCs. IPCE response could not be simply enhanced by increasing the $\mathrm{PbS}$ layer thickness because it eventually led to either inefficient hole injection or overall carrier recombination.

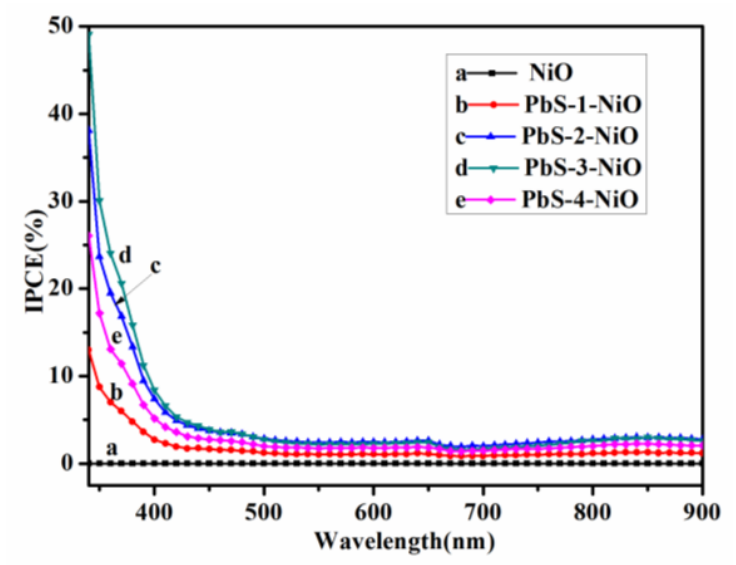

Figure 7. IPCE of pure and $\mathrm{PbS}$-modified $\mathrm{NiO}$ films fabricated using 1-4 CBD cycles

\subsection{EIS spectrum}

EIS data of an electrode containing NiO/PbS-3 film in comparison with EIS for Pt and pure NiS electrode are shown in Figure. 8. EIS parameters were obtained a Z-view software (as shown in Figure 8 and Table 3). In the high-frequency domain, the curve intercept with the real axis is equal to the ohmic series resistance (Rs) of the substrate. The left semicircle in the middle frequency domain represents the charge-transfer resistance (Rct) at the electrode-electrolyte interface. A semicircle in a low-frequency domain reflects the impedance due to the Nernst diffusion $(\mathrm{ZN})$ of the charged species in an electrolyte. Rs value of the pure NiS electrode was $18.1 \Omega / \mathrm{cm}^{2}$, which was less than that of the Pt-electrode 
(which was equal to $27.4 \Omega / \mathrm{cm}^{2}$ ). This indicates a strong interaction between the Pt CE and surface sulfide species (e.g., S2-, Sn2-). Rct value directly correlated to the CE catalytic activity, determined by the semicircle radius.35 The Rct values of $\mathrm{Pt}$ and NiS CEs were to 3.27 and $1.42 \Omega / \mathrm{cm}^{2}$, respectively. Small Rct value for NiS CEs indicates its excellent catalytic activity towards ((CH3)4N)2S/((CH3)4N)2Sn reduction because Rct varies inversely proportional to the $\mathrm{CE}$ electrocatalytic activity. The $\mathrm{ZN}$ values fo $\mathrm{rPt}$ and $\mathrm{NiS}$ electrodes were 11.75 and 5.64 $\Omega / \mathrm{cm}^{2}$, respectively. Thus, NiS CE had better catalytic activity than Pt CE, which would translate into better photovoltaic performance.

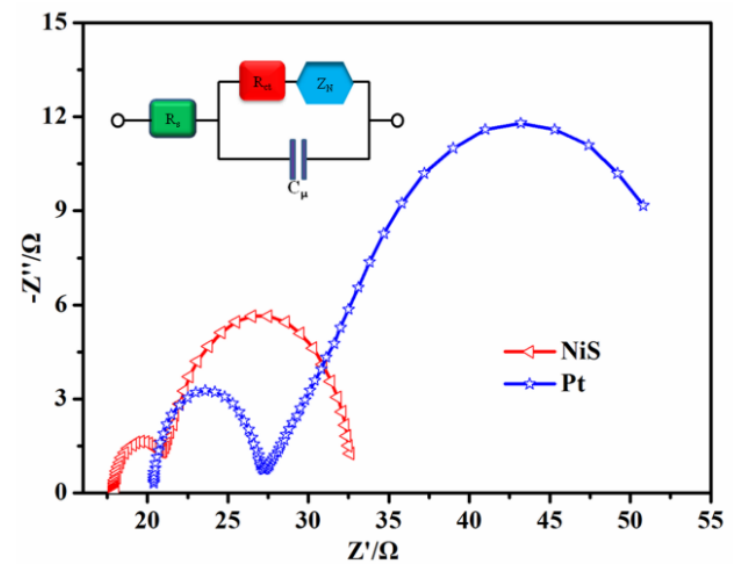

Figure 8. Nyquist plots of the sacrificial cells. Insert shows an equivalent circuit diagram used to fit EIS data

Table 3. Rs, Rct and ZN (all in $\Omega / \mathrm{cm}^{2}$ ) values for CE cells

\begin{tabular}{cccc}
\hline $\mathbf{C E s}$ & $\mathbf{R}_{\mathbf{s}}\left(\boldsymbol{\Omega} / \mathbf{c m}^{2}\right)$ & $\mathbf{R}_{\mathrm{ct}}\left(\mathbf{\Omega} / \mathbf{c m}^{2}\right)$ & $\mathbf{Z}_{\mathbf{N}}\left(\mathbf{\Omega} / \mathbf{c m}^{2}\right)$ \\
\hline $\mathrm{NiS}$ & 18.1 & 1.42 & 5.64 \\
$\mathrm{Pt}$ & 27.4 & 3.27 & 11.75 \\
\hline
\end{tabular}

\section{CONCLUSIONS}

We successfully synthesized $\mathrm{NiO}$ films with urchin-like morphology using a high-temperature hydrothermal method. $\mathrm{PbS}$ was deposited on $\mathrm{NiO}$ film using the CBD process. $\mathrm{NiO} / \mathrm{PbS}$ composites with different $\mathrm{PbS}$ thicknesses were performed. Thickness was varied by a different number of the CBD cycles. The resulting composites were then used as active materials for QDSC photoanodes. Yield (Voc), ff, Jsc, and the cell efficiency values of the solar cell containing $\mathrm{PbS} / \mathrm{NiO}$ composite fabricated using three $\mathrm{CBD}$ cycles were $0.538 \mathrm{~V}, 0.23 \%, 8.53 \mathrm{~mA} \mathrm{~cm}^{-2}$, and $1.07 \%$, respectively. The IPCE value of this electrode was $49 \%$ at $340 \mathrm{~nm}$. This is the better IPCE value reported in the literature for p-type QDSCs. Thus, $\mathrm{PbS}$ sensitized urchin-like $\mathrm{NiO}$ structures are excellent candidates as photocathode active material to produce very efficient p-type solar cells.

\section{ACKNOWLEDGMENT}

We gratefully acknowledge the financial support from the following sources: Supported by President Foundation of Hebei University (Grant No.: XZJJ201918).

\section{REFERENCES}

[1] Holtzer, M.E., Holtzer, A. (1995). The use of spectral decomposition via the convex constraint algorithm in interpreting the CD-observed unfolding transitions of $\mathrm{C}$ coils. Biopolymers: Original Research on Biomolecules, 36(3): 365-379. https://doi.org/10.1002/bip.360360310

[2] Kamat, P.V. (2008). Quantum dot solar cells. Semiconductor nanocrystals as light harvesters. The Journal of Physical Chemistry C, 112(48): 18737-18753. https://doi.org/10.1021/jp806791s

[3] Mora-Sero, I., Giménez, S., Fabregat-Santiago, F., Gómez, R., Shen, Q., Toyoda, T., Bisquert, J. (2009). Recombination in quantum dot sensitized solar cells. Accounts of Chemical Research, 42(11): 1848-1857. https://doi.org/10.1021/ar900134d.

[4] Nozik, A.J., Beard, M.C., Luther, J.M., Law, M., Ellingson, R.J., Johnson, J.C. (2010). Semiconductor quantum dots and quantum dot arrays and applications of multiple exciton generation to third-generation photovoltaic solar cells. Chemical Reviews, 110(11): 6873-6890. https://doi.org/10.1021/cr900289f

[5] Yella, A., Lee, H.W., Tsao, H.N., Yi, C., Chandiran, A. K., Nazeeruddin, M.K., Diau, E.W., Yeh, C.Y., Zakeeruddin, S.M., Grätzel, M. (2011). Porphyrinsensitized solar cells with cobalt (II/III)-based redox electrolyte exceed 12 percent efficiency. Science, 334(6056): https://doi.org/10.1126/science. 1209688

[6] Anta, J.A., Guillén, E., Tena-Zaera, R. (2012). ZnObased dye-sensitized solar cells. The Journal of Physical Chemistry $\quad$ C, 116(21): 11413-11425. https://doi.org/10.1021/jp3010025

[7] Chappel, S., Zaban, A. (2002). Nanoporous $\mathrm{SnO}_{2}$ electrodes for dye-sensitized solar cells: improved cell performance by the synthesis of $18 \mathrm{~nm} \mathrm{SnO}_{2}$ colloids. Solar Energy Materials and Solar Cells, 71(2): 141-152. https://doi.org/10.1016/S0927-0248 (01)00050-2

[8] Santra, P.K., Kamat, P.V. (2012). Mn-doped quantum dot sensitized solar cells: a strategy to boost efficiency over 5\%. Journal of the American Chemical Society, 134(5): 2508-2511. https://doi.org/10.1021/ja211224s

[9] Leschkies, K.S., Divakar, R., Basu, J., Enache-Pommer, E., Boercker, J.E., Carter, C.B., Kortshagen, U.R., Norris, D.J., Aydil, E.S. (2007). Photosensitization of $\mathrm{ZnO}$ nanowires with CdSe quantum dots for photovoltaic devices. Nano Letters, 7(6): 1793-1798. https://doi.org/10.1021/n1070430o

[10] Gónzalez-Dominguez, J.M., Gonzalez, M., AnsonCasaos, A., Diez-Pascual, A.M., Gomez, M.A., Martinez, M.T. (2011). Effect of various aminated single-walled carbon nanotubes on the epoxy cross-linking reactions. The Journal of Physical Chemistry C, 115(15): 72387248. https://doi.org/10.1021/jp110830y

[11] He, J., Lindström, H., Hagfeldt, A., Lindquist, S.E. (1999). Dye-sensitized nanostructured p-type nickel oxide film as a photocathode for a solar cell. The Journal of Physical Chemistry B, 103(42): 8940-8943. https://doi.org/10.1021/jp991681r

[12] Peter, L.M. (2007). Characterization and modeling of dye-sensitized solar cells. The Journal of Physical Chemistry $\quad$ C, 111(18): 6601-6612. https://doi.org/10.1021/jp069058b 
[13] Wang, Z., Shakya, A., Gu, J., Lian, S., Maldonado, S. (2013). Sensitization of p-GaP with CdSe quantum dots: Light-stimulated hole injection. Journal of the American Chemical Society, 135(25): 9275-9278. https://doi.org/10.1021/ja403701p

[14] Kang, S.H., Zhu, K., Neale, N.R., Frank, A.J. (2011). Hole transport in sensitized $\mathrm{CdS}-\mathrm{NiO}$ nanoparticle photocathodes. Chemical Communications, 47(37): 10419-10421. https://doi.org/10.1039/C1CC13932K

[15] Rhee, J.H., Lee, Y.H., Bera, P., Seok, S.I. (2009). Cu2Sdeposited mesoporous $\mathrm{NiO}$ photocathode for a solar cell. Chemical Physics Letters, 477(4-6): 345-348. https://doi.org/10.1016/j.cplett.2009.07.014

[16] Bachmeier, A., Hall, S., Ragsdale, S.W., Armstrong, F.A. (2014). Selective Visible-Light-Driven $\mathrm{CO}_{2}$ Reduction on a p-Type Dye-Sensitized NiO Photocathode. Journal of the American Chemical Society, 136(39): 1351813521. https://doi.org/10.1021/ja506998b

[17] He, J., Lindstrom, H., Hagfeldt, A., Lindquist, S.E. (2000). Dye-sensitized nanostructured tandem cell-first demonstrated cell with a dye-sensitized photocathode. Solar Energy Materials and Solar Cells, 62(3): 265-273. https://doi.org/10.1016/S0927-0248(99)00168-3

[18] Safari-Alamuti, F., Jennings, J.R., Hossain, M.A., Yung, L.Y.L., Wang, Q. (2013). Conformal growth of nanocrystalline $\mathrm{CdX}(\mathrm{X}=\mathrm{S}, \mathrm{Se})$ on mesoscopic $\mathrm{NiO}$ and their photoelectrochemical properties. Physical Chemistry Chemical Physics, 15(13): 4767-4774. https://doi.org/10.1039/C3CP43613F

[19] Mori, S., Fukuda, S., Sumikura, S., Takeda, Y., Tamaki, Y., Suzuki, E., Abe, T. (2008). Charge-transfer processes in dye-sensitized NiO solar cells. The Journal of Physical Chemistry $\quad$ C, 112(41): 16134-16139. https://doi.org/10.1021/jp803919b

[20] Li, L., Gibson, E.A., Qin, P., Boschloo, G., Gorlov, M., Hagfeldt, A., Sun, L. (2010). Double-layered NiO photocathodes for $\mathrm{p}$ - type DSSCs with record IPCE. Advanced Materials, 22(15): 1759-1762. https://doi.org/10.1002/adma.200903151

[21] Lu, Q., Li, L., Xiao, J., Sui, H., Li, J., Duan, R., Li, J., Zhang, W., Li, X., Yang, K., Zhang, Y., Wu, M. (2017). Assembly of CdS nanoparticles on boron and fluoride codoped $\mathrm{TiO}_{2}$ nanofilm for solar energy conversion applications. RSC Advances, 7(46): 29065-29070. https://doi.10.1039/C7RA03071A

[22] Sullivan, I., Zoellner, B., Maggard, P.A. (2016). Copper (I)-based p-type oxides for photoelectrochemical and photovoltaic solar energy conversion. Chemistry of Materials, 28(17): 5999-6016. http://doi.org/10.1021/acs.chemmater.6b00926

[23] Chen, H.M., Chen, C.K., Chang, Y.C., Tsai, C.W., Liu, R.S., Hu, S.F., Chang, W.S., Chen, K.H. (2010). Quantum dot monolayer sensitized $\mathrm{ZnO}$ nanowire-array photoelectrodes: true efficiency for water splitting. Angewandte Chemie International Edition, 49(34): 5966-5969. https://doi.org/10.1002/ange.201001827

[24] Yu, W.W., Qu, L., Guo, W., Peng, X. (2003). Experimental determination of the extinction coefficient of CdTe, CdSe, and CdS nanocrystals. Chemistry of Materials, $\quad$ 15(14): 2854-2860. http://doi.org/10.1021/cm033007z
[25] Bolton, J., Bailey, T.S., Rzayev, J. (2011). Large pore size nanoporous materials from the self-assembly of asymmetric bottlebrush block copolymers. Nano Letters, 11(3): 998-1001. https://doi.10.1021/nl103747m

[26] Wang, P., Wang, L., Ma, B., Li, B., Qiu, Y. (2006). $\mathrm{TiO}_{2}$ surface modification and characterization with nanosized $\mathrm{PbS}$ in dye-sensitized solar cells. The Journal of Physical Chemistry B, 110(29): 14406-14409. https://doi.org/10.1021/jp060390x

[27] Rhee, J.H., Lee, Y.H., Bera, P., Seok, S.I. (2009). Cu2Sdeposited mesoporous $\mathrm{NiO}$ photocathode for a solar cell. Chemical Physics Letters, 477(4-6): 345-348. https://doi.org/10.1016/j.cplett.2009.07.014

[28] Raissi, M., Pellegrin, Y., Jobic, S., Boujtita, M., Odobel, F. (2016). Infra-red photoresponse of mesoscopic NiObased solar cells sensitized with $\mathrm{PbS}$ quantum dot. $\begin{array}{llll}\text { Scientific } & \text { Reports, } & 6(1): & \text { 1-7. }\end{array}$ https://doi.org/10.1038/srep24908

[29] Wang, R., Li, Q., Xie, D., Xiao, H., Lu, H. (2013). Synthesis of $\mathrm{NiO}$ using pine as template and adsorption performance for $\mathrm{Pb}$ (II) from aqueous solution. Applied Surface $\quad$ Science, 279 : 129-136. https://doi.org/10.1016/j.apsusc.2013.04.049

[30] Zheng, K., Žídek, K., Abdellah, M., Zhang, W., Chábera, P., Lenngren, N., Yartsev, A., Pullerits, T. (2014). Ultrafast charge transfer from CdSe quantum dots to $\mathrm{p}$ type NiO: hole injection vs hole trapping. The Journal of Physical Chemistry C, 118(32): 18462-18471. https://doi.org/10.1021/jp506963q

[31] Magrini, A., Lazzari, S., Marenco, L., Guazzi, G. (2017). A procedure to evaluate the most suitable integrated solutions for increasing energy performance of the building's envelope, avoiding moisture problems. International Journal of Heat and Technology, 35(4): 689-699. https://doi.org/10.18280/ijht.350401

[32] Hariharan, G., Moorthi, N.S.V., Karthickeyan, D., Thanikaikarasan, S. (2019). Influence of annealing temperature on the characteristics of chemical bath deposited zinc sulphide thin films for solar cell applications. Journal of New Materials for Electrochemical Systems, 22(1): 1-4. https://doi.org/10.14447/jnmes.v22i1.a01

[33] Santra, P.K., Kamat, P.V. (2012). Mn-doped quantum dot sensitized solar cells: A strategy to boost efficiency over 5\%. Journal of the American Chemical Society, 134(5): 2508-2511. https://doi.org/10.1021/ja211224s

[34] Gónzalez-Dominguez, J.M., Gonzalez, M., AnsonCasaos, A., Diez-Pascual, A.M., Gomez, M.A., Martinez, M.T. (2011). Effect of various aminated single-walled carbon nanotubes on the epoxy cross-linking reactions. The Journal of Physical Chemistry C, 115(15): 72387248. https://doi.10.1021/jp110830y

[35] Takahashi, Y., Kobayashi, Y., Wang, Z., Ito, Y., Ota, M., Ida, H., Kumatani, A., Miyazawa, K., Fujita, T., Shiku, H., Korchev, Y.E., Miyata, Y., Fukuma, T., Chen, M., Matsue, T. (2020). High-resolution electrochemical mapping of the hydrogen evolution reaction on transition-metal dichalcogenide nanosheets. Angewandte Chemie-International Edition, 59(9): 36013608. https://doi.org/10.1002/anie.201912863 